\title{
Factors Affecting Students Attraction Towards Jordanian University
}

\author{
Dima Musa Al-Dajani ${ }^{1} \&$ Mahmood Jasim Alsamydai ${ }^{1}$ \\ ${ }^{1}$ Department of Marketing, Faculty of Business, AL-Zaytoonah University of Jordan, Jordan \\ Correspondence: Mahmood Jasim Alsamydai, Department of Marketing, Faculty of Business, AL-Zaytoonah \\ University of Jordan, Jordan.
}

Received: November 13, 2018

Accepted: December 4, 2018

Online Published: January 4, 2019

doi:10.5430/ijba.v10n1p49

URL: https://doi.org/10.5430/ijba.v10n1p49

\begin{abstract}
The aim of this study is to investigate the factors influencing the attraction of students' selection of Jordanian universities. For this purpose a model has been designed to test these factors. The model is divided into seven dimensions including: university's attributes, economic factors, Geographic factors, reference groups and marketing communication, Attraction and Selection University.

Seven hypotheses were developed based on the dimensions of the study as well as the relevant literature to achieve this aim, the researchers used a convenience sampling technique. A total of (321) respondents completed the research questionnaire, which distributed in (6) private universities which located in Amman. The distributed questionnaire consists of (35) questions that measured using a 5 points liker scale.

The collected data were analyzed by using SPSS for descriptive statistic and AMOS analysis to assess the structural and measurement model for the proposed study model.

The findings indicated that is an impact of all factors on the attraction of students for selection universities.

Also, the findings showed the complementary partial role of attraction between the study factors and students' selection for universities.
\end{abstract}

Keywords: university attributes, attraction, economic factors, marketing communication

\section{Introduction}

The huge demand on college education as expansion the numbers' of colleges and Universities, and relatively, expansion is the number of new produced programs. Education is simply, some type of business. Services, and with the deductions in the official support, the shortage of donations from major sponsors, and the strong competition, educational organizations went in the last ten years to employ marketing capabilities to attract potential students and academic staff. Also they used marketing to present their advantages, images and their achievements.

Today, student attraction is one of the most important problems and issues for universities. They have to try to attracting more volunteers or students to meet their financial needs (Jafari and Aliesmaili, 2013).

One major issue, which became subject for many researchers, is: what are the factors affecting the choice of college or university, concerning undergraduate students?

We will present in this paper, briefly, some selections of those researches and opinions. Also we will present the summary of those factors and some classifications for them.

The growth in Business fields and sectors caused a tremendous increase in the number and type of programs at colleges and universities not just only in USA but also over the whole world. (So Jung Lee and Hyun Kyung Chatfield; May 2013).

The study of lee and Chatfield, 2013, identified factors that influence students 'choices among three groups: in-state, out-of-state, and international students. The study utilized exploratory factor analysis to identify appropriate factors and multivariate analysis of variance to determine differences in college choices among the three groups. The results of this research will be beneficial to colleges in the development appropriate promotions to differentiate themselves in a meaningful way to potential student. (So Jung Lee and Hyun Kyun Chatfields; May 2013).

The significant factors used to choose among in-state out-of-state and international students might not be the same. Tuition and financial aid are different for each of these groups. In some states there are more scholarships available 
for in-state applicants to encourage attracting more high-achieving students, Job opportunities during and after graduation are not the same. Also the reputation or recognition of a collage might be different internationally and domestically. This could affect job opportunities for students in their own countries. Therefore, it is assumed that the significance of the various factors is not the same among these three groups of students.

The 2009 Lipmann Hearne paper sampled both public and private college students. The study investigated the importance of the total costs versus location. Program reputation and overall reputation. The study found economic downturns do affect some students' chose of institutions. They found solid performer students are more likely to enroll at a public institution in an economic downturn. The study differentiated between academic superstars and solid performance based upon SAT scores (Scholastic Assessment Test and Scholastic Aptitude Test).

ALipman Hearne report (2009) claimed parents are deeply involved and influential to their high achieving children's college choices. The report also found open houses, dialogue with college friends, alumni and admitted-student-programs are extremely influential to student. The report claimed these sources are not well known, but very powerful to student's decision making for their college. The study also found $26 \%$ of sampled students paid a specialist or advisor during the college decision process.

The purpose Norman and A vinash study, 2017 was to determine factors that influenced decisions of undergraduate students' choice of a university to study at Botho University was used as a case study. Studies show that universities are currently confronted with both the decrease in student enrolments and high competition for those students between institutions. As a result of these twin challenges, it is of critical importance that factors that influence students' choices of universities are investigated to enable effective planning of student recruitment strategies.

\section{Literature Review}

Dresher and Poutvaara 2005 have suggested that economic and cultural forces play an important role in shaping the international students migration markets. Second, the national level discusses the choice of higher education institution within countries. In Australia, for example, James et al.1999 found that field of study preferences characteristic significantly influence applicant' choice of institution, In addition, the teaching reputation of universities has been more important for college students in England than their research profiles.9 price,2003).

Foskett, 2006, found that students consider more carefully economic factors in times of distress and financial difficulty. These factors include job opportunities to supplement their incomes, accommodation costs and family home proximity. Third, course of study decisions tend to be closely related to institutional choice decisions.

James et al. (1999) has identified a range of factors influencing course preference including: the reputation of the course: the quality of teaching in the course; approaches to teaching, learning and assessment from the course including opportunities for flexible study.

Two different perspectives to understanding the complex college selection decision have emerged, One approach focuses on how aspiring students develop a college choice set, decide where to apply considering admission criteria, and make their enrollment decisions (Hearn,1984). Geography also imposes constrains on college choices. That most students attend public, in-state institutions implies that college option is circumscribed by state of residence (Niue and Tined, 2008). The second approach emphasized institutional characteristics such as cost, size, distance, the quality of programs, and availability of financial aid. The factors most commonly associated with comprehensive college choice model include student background characteristics (Jackson, 1982) aspirations (Chapman, 1984; Jackson, 1982).

Educational achievement (Hanson and litten, 1982;Jackson,1982),social environment (Hossler and Gallagher,1987), financial variables (St John,1990;1991), net cost (St John and Starkey,1995) institutional climate( Chapman,1984), and institutional characteristics (Hanson and litten,1982; Hostler et al.,1989). The study of So Jung Lee and Hyun Kyung Chatfield, May2013, selected a conceptual framework for college that Somers, Haines, Keene (2006) constructed for 2-years choice eight factors.

The atmosphere of higher education has increasingly become competitive, and institutions have to compete with each other to attract students in the recruitment markets (Marring, 2006). There are many research studies about factors influencing student's university choice in the world, these can be categorize in three level containing national levels (Bidet and Newman, 2001), international level (e.g. Choy Chung, 2009), and both (Kee Ming, 2010).

Javari and Aliesmaili conducted a study and research in 2013, on north Iran universities, which tried to find answers to the following questions:

1-Which factors influence choice of university among (Iranian) students? 


\section{2-How significant each factor is?}

3-What model of attracting students can be developed or higher education system?

In their study they concluded that: In order to recognize factors influencing university choice pre-university students, four sets of factors (categories) were determined including:

1-Economic Factors (category)

2-University-related factors (categories)

3-Personal Factors (category)

4-Social Factors (categories)

Kolter and Armstrong (1994) describe the stages through which buyers supposedly pass to reach a buying decision. Need recognition is triggered when the buyer recognizes a need or a problem. It is followed by information search, an evaluation of alternatives and a purchase decision. According to kolter and Armstrong (1994), the purchase decision derives from the consumer ranking the alternatives to formulate a purchase decision

Two factors may however intervene. The first is the attitude and will depend upon both the strength of the other person's attitude towards the buying intention and the consumer's motivation to comply with the person's wishes. For the potential student this could include parental attitude and opinions of "availability of university-owned accommodation" was, hardly surprisingly. Significantly the lowest for three institutions were "proximity to home".

In Australia, James et al. (1999) have found that: field of study preferences, course and institutional reputations. Course entry scores, easy access to home and institutional characteristics in that order exert significant influence on applicants'

Previous Studies about factors Influencing Undergraduate Students' Decision to Choose a University Norman Rudhumbu, Avinash and Kumari (2017), produced a study about Botho University in Botswana to determine factors that influenced decisions of undergraduate students' choice of a university to study at. The results of the study showed that factors include academic programmers offered, image and reputation of the institution, Advertising career fairs, quality of staff, employment prospects of graduates from the institutions had a very high influence on the decision of the students to choose Botho University as an institution to study at. Factors such as tuition fees, chance of getting scholarships and campus did not have high influence.

A number of studies have shown that there are a number of factors related to personal and individual characteristics of students, the role of other people, students, perceptions about value and costs, as well as institutional characteristics that influence students' decisions to choose a university for study (Ming, 2010). A study by Yusof et al (2008) found that availability of the required programmes and financial assistance such as scholarship were some of the influential factors in the way students' decide to choose a particular university.

Other studies for example by Ariffin et al (2008) and also Keling et al (2007) found that marketing strategies were influential while a study by Milsom and Coughlin (2015) and also by Keling et al (2006) found that institutional image and reputation, tuition fees, and academic programs had a high explanatory power an how the students decide on which university to study at. The importance of quality, type and variety of academic programs as well as the presence of distinguished teaching staff were factors raised in a study of Ali et al, (2016) as having a moderating effect on students' decisions to choose a university to study. Ivy (2008), in her study, also found that educational facilities as well as conveniences such as parking areas and sporting facilities had a significant predicative influence on students' decisions to choose a university.

Shankar et al(2006) Banneker et al (2010) and also Karl and Yousef (2009) in their different studies also found that location of the institution as well as opinion of other people such as parents, friends, teachers and others had significant moderating influence on how students choose universities to study at. Mubaiira and Fatoki (2012) in their study found that access to learning facilities such as information communication technology(ICT), cultural diversity, international partnerships, institutional social life, admission requirements, flexible study modes, and campus attractiveness had significant influence on how students make their choices. Clark and Hossler (1990) explain how institutions position themselves in the market. For example, a college can position itself" as an elite college ..., a low -cost pathway to upward mobility ... (or) church-related school "(Clerk and Hossler, 1990, page 78).

According to Kotler (1982) an institution markets itself by" deigning the organization's offering in terms of the target markets" needs and desires, and ... using effective pricing, communication, and distribution to inform, motivate, and service the markets' (page 6). 
As part of its market plan, an institution must determine who to contact in an effort to influence student college choice decisions. Although research has found that friends, relatives, teachers, and fellow employees of prospective students have an influence on college choice, institutions typically do not have an immediate access to these individuals (Allen, 1984; Brook dale, 1983; Campbell and smith, cibic, 1982; Lucas, 1984; Johnson, Stewart and Eberly, 1991).

Colleges and universities can use the American College Testing Program student profile (ACT profile) information contact students as well as parents, when the student lists the institution on their choice set.

The institution may contact students who applied but failed to enroll at the institution, using data from the admission application. Staff may participate in college visit days with students at local high schools. Other possibilities include contact with high school counselors or employers in the area. Parents may have the greatest influence on a student's college choice (Brookdale, 1983; Carnegie foundation, 1986; Lucas, 1984; seegmiller, 1975) and they have an effect on whether a student attends a community college, four-year institution, or highly selective private college (Conklin and Dailey, 1981; keller 1984. Despite strong parental influence, the high school counselor can also be an important source of information for many students (bradshaw. E Spinoza and Hausman2001)

Colleges and universities can encourage visits to campus which has been shown to be a very powerful factor in student college choice (Jonas and Popovics) Kellaries. 1988) Receipt of the semester course schedule in the mail has proven highly effective (Lucas, 1984). The college web site has become one of the most helpful or influential sources of information (Seymour, 2000). Colleges and universities also inform students via college guides, brochures and college catalogues sent in the mail.(Jonas and popvics,1990) .Other possibilities involve activities or events on campus, literature at work or in the high schools, advertismentsin the newspaper, on radio or television, student telemarketing, scholarship interviews early registration programs, and use of alumni networks.

Although the junior year is typically when students become familiar with the characteristics of different colleges and universities Although focus groups and student interviews are useful in obtaining valuable qualitative information about student perceptions of an institution, an understanding of the students markets also involves quantities analysis and survey research. Institutions may develop their own-in-house survey or use one of the standardized instruments available such as The Admitted Students Questionnaire (ASQ) OR Cooperative Institutional Research Program Freshmen Survey (CIRP).

The Admitted Student Questionnaire plus (ASQ Plus) also allows institutions to obtain student ratings on competing institutions. The ACT Profile and the college Boards student Descriptive Questionnaire (SDQ) Provide information on college choice; however, the number of questions regarding institutional characteristics is more limited compared with ASQ or CIRP. Students do not rate the importance of college characteristics on the SDQ; whereas, this is part of the other instruments. Matthews and Hadley (1993) developed the student perceptions of Institutional Quality (SPIQ) Instrument to compare several state institutions on several measures of quality. The National center for Education statistics (NCES) IN ITS National Education Longitudinal Study of 1988 (NELS) Also requests information on college choice factors.

Data from these surveys are obtained from high school students who will be either matriculate or nomatriculate at colleges. The typical information sought from surveys not only includes student perceptions about colleges and universities, but also data on high school preparation, student characteristics, majors, interests, financial aid offers, institutions where students will attend, the effectiveness of recruiting methods.Sources of information used by students, the influence of people in the choice process, and so on.

Researchers may not only ask how important various factors are in a student's choice of an institution, but also the extent to which a specific institution is believed to have these attributes-the expectancy value model. Other researchers have measured a student'sconception of an ideal college and then compared institutions against it ideal point preference model. When the same student rates two competing institutions, the Researcher can calculate a difference score. This score is valuable in prediction and is used to display a balance sheet on competing institutions.

The draw rate is a descriptive static showing whether a competitor is outdrawing another institution or attracting more students who have both institutions in their choice set. Advanced statistics provide further understanding of the data. Researchers may use regression, discriminant, probity and legit analysis to predict matriculation at the institution... Factor analysis may be used to identify market segments or to combine several related questions into one factor for prediction. Multi-dimensional scaling produces a visual map of institutions, which shows the similarity or dissimilarity among competing institutions. 
Regardless of the methods, the ultimate goal is to gain a clear picture of an institution image and it's position relative to competitors. Researchers may use many instruments to improve their studies and produce the required data analysis. Standardized instruments had a limit set of factors with CIRP survey being the most comprehensive. The CIRP survey lists 17 choice factors for rating institutional characteristics.

We would like to produce the summary of factors of more than 27 researchers that took the subject of factors that influence the choice of university by students as main issue in their researches and surveys.

The most important 21 factors that were repeated in these studied are in these following:

Nine factors placed in the number one categories across several studies (the most frequent listed first): academic reputation, location, quality, of instruction, availability of programs, and quality of faculty, costs reputable program, financial aid and job outcomes.

These factors also frequently placed within the top three, top five, and top ten categories. A measure of the costs of attendance was the only factor included on all four of the standardized instruments discussed above.

The next twelve most important factors across the twenty two studies were: a variety of courses offered, size of the institution, surrounding community, availability of graduate programs, students employment opportunities, quality of social life, class ,size graduate school outcomes, extracurricular program, friendly /personal service, affiliation, admission requirements and attractiveness of campus facilities.

Several of these choice factors are not included on standardized instruments. Several factors included on the standardized instruments also never made the top ten ranking.

The above factors may be classified into group or categories as in the following:

-university attributes

-economic factors

-geographic factors

-reference groups and social factors

-marketing communication

Before the final end, we would like to mention here that the effect or weight of each factor may differ from country to country .Also it may be changed according to changes in the financial status of the student or his family or in his surrounding environment.

Due to these results, we also believe and degree with the researchers that more work is needed to develop standardized instruments for studying college choice. We believe that in -house instruments provide useful information that supplements national data sets.

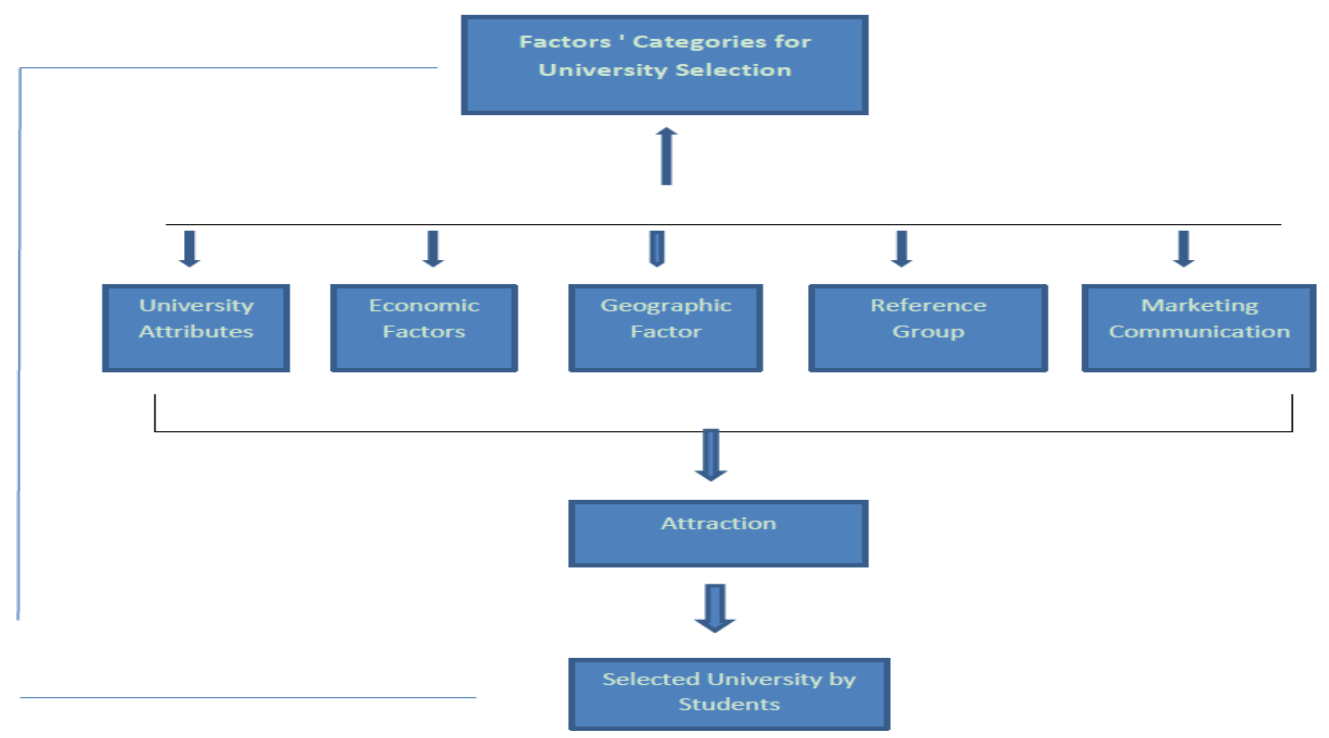

Figure 1. Study model 
Please note that this classification is more comprehensive than the one presented by Jafari and Aliesmaili,

Before the final end, we would like to mention here that the effect or weight of each factor may differ from country to country (sometimes from state to state). Also it may be changed according to change in the financial status of the student or his family or in his surrounding environment.

Due to these results, we also believe and agree with the researchers that more work is needed to develop a standardized instrument for studying college choice. We believe that in-house instruments provide useful information that supplements national data sets.

\section{Research Questions}

There are some studies in literature about the factors influencing the choice of university among students.

This study considers to determine the factors influencing the attraction to university among Students.

There are a number of factors, but does such attraction affect the selection of University?

The following sub-questions will attempt to answer this larger question:

_What is the impact of factors on attraction and university selection?

-Is there an effect of university attribute on attraction to university selection?

-Is there an effect of economic factors on attraction to university selection?

-Is there an effect of Geographic factors on attraction to University Selection?

-Is there an effect of Reference group on attraction to University selection?

-Is there an effect of Marketing Communication on attraction to university Selection.

- Is there an effect of attraction factors to university selection?

\section{Objective}

The objectives of this study concern the determination of the impact of factors attraction to university selection, which was done by the following:

-Determine the impact of the university attributes on the attraction to university selection.

-Determine the impact of economic factors on attraction to university selection.

-Determine the impact of Geographic factors on attraction to university selection

-Determine the impact of marketing communication on attraction to university selection -Determine the impact of attraction factors on university selection

\section{Hypotheses}

Based on the objectives study questions and study model, the main hypothesis of this study is that:

H0: There is statistical not significance $(\&<=0.05)$ of the impact of attraction factors on university selection From the main hypothesis, we derive the following sub-hypotheses:

H01: There is statistical not significance $(\&<=0.05)$ of the impact of university attributes on attraction to university selection

H02: There is statistical not significance $(\&<=0.05)$ of the impact of economic factors on attraction to university selection

H03: There is statistical not significance $(\&<=0.05)$ of the impact Reference group on attraction to university selection

H04: There is statistical not significance $(\mathrm{a} c=0.05$ ) of the impact Geographic factors on Attraction to University Selection.

H05: There is statistical not significance $(\&<=0.05)$ of the impact marketing communication on attraction to university selection

H06: There is statistical not significance $(\&<=0.05)$ of the impact attraction factors on university selection

H07: There is statistical not significance $(\&<=0.05)$ of the impact number of factors on university selection. 


\section{Methodology}

\subsection{Tools}

Two main resources were used to gather information for this study: they are presented below:

\subsubsection{Secondary Resources}

These include data and information related to the abstract side, such as research, articles, books, scientific magazines, and foreign and Arabic theses related to the subject of the study.

\subsubsection{Primary Resources}

The primary resource was the study tool (questionnaire) and the data provided to the researcher from the research sample. The opinions of many specialists in the field, such as researchers, scholars, and author and university professors have been considered in finalizing the questionnaire and explaining its relation to the subject.

A five-point liker scale was used for questionnaire answers: (5) strongly agree, (4) agree (3) neutral, (2) disagree, and (1) strongly disagree.

\subsection{Study Sample}

A Sample of 35 university striations received the questionnaire. The returned were 321 copies of the questionnaire, for a response rate of $91-14 \%$

- Validity and stability of the study tool

- $\quad$ Apparent Validity

The questionnaire, in its initial form, was presented by the researcher to a group of specialized university professors of the academic staff and marketing section to obtain the benefits of their scientific knowledge and experience and to take into consideration their notes, comments and modifications to make the tool more accurate.

\subsection{Variance Inflation Factors (VIF)}

These are used to investigate whether there is any multi-linear interaction problem between independent variables or not.

From results found from Table 1, it is clear that there are no multi-linear interaction problems between independent variables, because all values for VIF are less than the critical value.

Table 1. Variance inflation factors

\begin{tabular}{lcccc}
\hline \multicolumn{1}{c}{ Study Variables } & \multicolumn{2}{c}{ Tolerance } & VIF & Critical Value \\
\hline University & 0.693 & 1.443 & 5 & \\
characteristic & & & 5 & \\
Economic Factor & 0.727 & 1.370 & 5 & 5 \\
Reference group & 0.811 & 1.233 & 5 \\
Geographic Factor & 0.770 & 1.299 & \\
Marketing & 0.512 & 1.955 & & \\
Communication & & & & \\
\hline
\end{tabular}

\subsection{Stability of the Study Tool}

Cranach's alpha test was used to measure the stability of the measurement tool (T) .The (a) value reached (0.5) for the entire questionnaire. This is a good result, since it is higher than the acceptance value $(0.70)$.

\subsection{Validity and Measurement of the Tools}

The researchers submitted the questionnaire to (18) referees of the university faculty members to verify its validity. Cronbach' Aspha coefficient has been used with a value of Cronbach's Alpha $(a=0,84)$ for all variable of the study.

Table 2. Reliability coefficient

\begin{tabular}{lll}
\hline No. of cases & Cronbach's Alpha & No.of items \\
\hline 321 & 0,84 & 35 \\
\hline
\end{tabular}




\section{The results and Discussion}

By using descriptive analysis it was determined that the mean of all questions are over the midpoint (3).

Test results of the set of hypotheses of the study are shown in table 2. Statistical analysis of this illustrates in overall mean score of respondent which measures the (D1, D2, D3, D4, D5, D6 and D7) that corresponds the five hypotheses. The mean values of these are $\mathrm{H} 1=4.17, \mathrm{H} 2=4.11, \mathrm{H} 3=3.47, \mathrm{H} 4=4.13$. $\mathrm{H} 5=5.54, \mathrm{H} 6=4.07, \mathrm{H} 7=4.08$. These values are above the scale midpoint (3).

Table 3. Means and std. deviation

\begin{tabular}{lll}
\hline Damintation and Hypothesis & $\begin{array}{l}\text { Test value=3 } \\
\text { Mean }\end{array}$ & Std. Dev. \\
\hline D1(University Attributs) H1 & 4.17 & 0.889 \\
D2 (Economic factors) H2 & 4.11 & 0.923 \\
D3 (Geographic Factor) H3 & 3.47 & 1.086 \\
D4 (Reserence Group) H4 & 4.13 & 0.83 \\
D5 ( Marketing communication ) H5 & 4.54 & 0.961 \\
D6 (Attraction) H6 & 4.07 & 0.841 \\
D7 ( Selected University by students) H7 & 4.08 & 0.855 \\
\hline
\end{tabular}

\subsection{The statistical Treatment Used in the Study}

The researcher relied on a number of statistical test (Cranach's alpha factor: Pearson correlation coefficient and multiple regress analysis) to support the study objectives and hypotheses using the (SPSS) program.

\subsection{The Statistical Treatment Used in the Study}

The researcher relied on a number of statistical test (Cranach's alpha factor: Pearson correlation coefficient and multiple regress analysis) to support the study objectives and hypotheses using the (SPSS) Program.

\subsection{Test Results for Intermediate Variable Hypothesis (H6)}

H0: There is no impact, of statistical indication at moral level $(a=0.05)$, for independent variables represented by $(\mathrm{H} 1, \mathrm{H} 2, \mathrm{H} 3, \mathrm{H} 4, \mathrm{H} 5)$ on the independent variable $(\mathrm{H} 7)$ through the variable $(\mathrm{H} 6)$ As an intermediate variable.

In order to test main hypotheses credibility, linear descending method was used, through (AMOS) program, as explained in the following Table 4.

Table 4. Results of linear descending analysis to measure impact of independent variables represented as (h1, h2, h3, $\mathrm{h} 4, \mathrm{~h} 5$ ), on the dependent variable (h7) through the variable (h6) as intermediate variable

\begin{tabular}{ccccc}
\hline Study Variables & Descending Factors (B) & Standard Error (S.E) & Calculated (t)value & Moral (t) (P-value) \\
\hline H1-H6 & 0.278 & 0.038 & 7.275 & 0.000 \\
H2 -H6 & 0.162 & 0.028 & 5.683 & 0.000 \\
H3 -H6 & 0.014 & 0.037 & -0.385 & 0.700 \\
H 4-H6 & 0.148 & 0.032 & 4.623 & 0.000 \\
H 5-H 6 & 0.086 & 0.036 & 2.403 & 0.016 \\
H 6-H 7 & 0.128 & 0.042 & 3.067 & 0.002 \\
H1-H7 & 0.036 & 0.031 & 12.649 & 0.000 \\
H -H7 & 0.021 & 0.056 & 12.649 & 0.000 \\
H3 -H7 & 0.002 & 0.032 & 12.649 & 0.000 \\
H 4-H7 & 0.011 & 0.035 & 12.649 & 0.000 \\
H 5-H7 & 0.019 & 0.044 & 12.649 & 0.000 \\
\hline
\end{tabular}

Analysis results, shown in Table 4, indicate that statistical is approved for four descending factors (B) related to (H1, $\mathrm{H} 2, \mathrm{H} 4, \mathrm{H} 5)$ that are related to direct impacts. That is approved by its calculated (t) values. 
Also that values for statistical indication for the mentioned variables are less than the moral level $(\mathrm{a}=0.05)$. Based on it, there is a direct impact, of statistical indication, at mentioned moral level $(\mathrm{a}=0.05)$ for mentioned variables in the independent variable (H7) through the variable (H6) as an intermediate variable.

In the light of previous results, the zero hypothesis ( $\mathrm{H} 0)$ was rejected and the alternative hypothesis (H1) was accepted which states: that there is a direct impact of statistical indication, at moral level $(a=0.05)$ for independent variables represented by $(\mathrm{H} 1, \mathrm{H} 2, \mathrm{H} 4, \mathrm{H} 5)$ on the dependent variable $(\mathrm{H} 7)$ through the variable (H6) as intermediate variable.

From another side, analysis results did not approve that the independent variable (H3) is morale.

Also results of Table 4 indicate the approval of statistical indication for all descending factors (B) related to (H1, H2, $\mathrm{H} 3, \mathrm{H} 4$, and $\mathrm{H} 5$ ) and that is connected to indirect impacts. Its calculated (t) values approve that.

Also the values of statistical indication, for the mentioned variables, are less than the moral level $(a=0,05)$. Based on it, there is indirect impact of statistical indication at moral level $(\mathrm{a}=0.05)$ for the mentioned variables in the dependent variable (H7) through the variable (H6) as intermediate variable.

Meanwhile, it is definitely approved that the statistical indication for descending factor (B) special for intermediate variable (H6) is related to direct impact. That is approved by its calculated value (t). Also the value of statistical indication for the mentioned variables less than the moral level $(a=0.05)$.

Based on it, there is direct impact of statistical indication at moral level $(a=0.05)$ for the intermediate variable (H6) in the dependent variable $(\mathrm{H} 7)$.

After hypothesis (H0) testing is finished, we should investigate the credibility of the five branches hypotheses that were derived from it.

In order to achieve this, the simple linear descending method issued, in the following table 5 explains this.

Table 5. Results of simple linear descending Analysis for analyzing direct and indirect impacts for independents variables represented by $(\mathrm{H} 1, \mathrm{H} 2, \mathrm{H} 3, \mathrm{H} 4, \mathrm{H} 5)$ in the dependent variable $(\mathrm{H} 7)$ through the variable (H6) as intermediate variable

\begin{tabular}{|c|c|c|c|c|c|}
\hline \multirow[t]{2}{*}{$\mathbf{S}$} & \multirow{2}{*}{$\begin{array}{l}\text { Study } \\
\text { Variables }\end{array}$} & \multicolumn{2}{|c|}{ Descending Factors ( B) } & \multirow{2}{*}{$\begin{array}{l}\text { Sum of Direct and } \\
\text { indirect Impacts }\end{array}$} & \multirow[t]{2}{*}{ Statistical Decision } \\
\hline & & H6 & H7 & & \\
\hline 1 & H1 & 0.278 & 0.036 & 0.314 & Reject H01 \\
\hline 2 & $\mathrm{H} 2$ & 0.162 & 0.021 & 0.183 & Reject H02 \\
\hline 3 & H3 & 0.014 & 0.002 & -0.016 & Reject H03 \\
\hline 4 & $\mathrm{H} 4$ & 0.148 & 0.011 & 0.159 & Reject H04 \\
\hline 5 & H5 & 0.086 & 0.019 & 0.105 & Reject H05 \\
\hline
\end{tabular}

From results shown in Table 5, the following issues become clear:

1-There is a direct impact of statistical indication at moral level $(\mathrm{a}=0.05)$ for the independent variable $(\mathrm{H} 1)$ on dependent variable (H7) through variable (H6) as an intermediate variable.

2-There is a direct impact of statistical indication at moral level (0.05) for the independent variable (H2) on dependent variable (H7) through variable (H6) as an intermediate variable.

3-There is a direct impact of statistical indication at moral level $(\mathrm{a}=0.05)$ for the independent variable $(\mathrm{H} 3)$ on dependent variable (H7) through variable (H6) as an intermediate variable.

4-There is a direct impact of statistical indication at moral level $(\mathrm{a}=0.05)$ for the independent variable $(\mathrm{H} 4)$ on dependent variable (H7) through variable (H6) as an intermediate variable.

5 -There is a direct impact of statistical indication at moral level $(\mathrm{a}=0.05)$ for the independent variable $(\mathrm{H} 5)$ on dependent variable (H7) through variable (H6) as an intermediate variable.

\section{Discussion and Conclusion}

The main objective of this study is to investigate the impact of the factors categories for university selection by students. Due to the increasing competition between HEI sector and satisfy their students and as all know that 
university reputation and Brand represents total perception of feelings tuition fees and teaching quality as well as logo and effective qualities that one play as vital factors to distinguish between universities.

Many factors play a large role in selected university by students: university Attributes, Economic, Geographic, Reference Groups and marketing communication.

The Importance of this study is the focuses on knowing factors categories for university selection.

This research will interpret and support the university in formulating its strategy to attract students to gain a competitive advantage. This can only be achieved when the university communicates and expresses itself into building its university brands and understanding the factors that drive attraction.

The survey design used in this study contract to measure factors categories for university selection, university attributes, Economic factors, Geographic Factors, Reference Group and Marketing Communication, Attraction and Selected University by Students.

The research will interpret and support the university in formulating its strategy to attract students to go a competitive advantage. This can only be achieved when university communicates and expresses itself building and understanding the factors that drive attraction to select the university.

The survey design used in this contract to measure the factors effected to select the university. The research instrument was a questionnaire consisting of all close ended questions.

The questionnaire was divided into four sections, section one to investigate the demographic profile of respondents, selection two to measure the factors effected students to elected university. five Dimensions, section three to measure the attraction and section four to measure the student's selected of university.

The selected sample was the private university which located in Amman and we choose six of them to apply the study on 32.0 Questions were distributed the returned was 321 only 312 was valid to analyze.

Finally, the data analysis process was conducted using SPSSV24 for Descriptive analysis using mean, standard deviation.

One $1 \mathrm{t}$ - simple $\mathrm{T}$ test, regression, Amos program

Test Results for Intermediate variable hypothesis (H6):

HO: There is no impact, of statistical indication at moral level $(\mathrm{a}=0,05)$, for independent variables represented by $(\mathrm{H} 1, \mathrm{H} 2, \mathrm{H} 3, \mathrm{H} 4, \mathrm{H} 5)$ on the independent variable $(\mathrm{H} 7)$ through the variable $(\mathrm{H} 6)$ as an intermediate variable.

In the light of previous results, the zero hypothesis ( $\mathrm{H} 0)$ was rejected and the alternative hypothesis ( $\mathrm{H} 1)$ was accepted which states: that there is a direct impact of statistical indication, at moral level $(a=0,05)$ for independent variable represented by $(\mathrm{H} 1 . \mathrm{H} 2, \mathrm{H} 4, \mathrm{H} 5)$ on the dependent variable $(\mathrm{H} 7)$ through the variable (H6) as intermediate variable.

Also the values of statistical indication for the mentioned variables, are less than the moral level $(\mathrm{a}=0,05)$ Based on it, there is indirect impact of statistical indication, at moral $(\mathrm{a}=0.05)$ for the mentioned variables in the dependent variable (H7) through the variable (H6) as intermediate variable.

In the light of previous results, the zero hypothesis (H0) was rejected and the alternative hypothesis (H1) was accepted which states : that there is indirect impact, of statistical indication at moral level $(a=0.05)$ for independent variables represented by $(\mathrm{H} 1, \mathrm{H} 2, \mathrm{H} 3, \mathrm{H} 4, \mathrm{H} 5)$ on the dependent variable $(\mathrm{H} 7)$ through the variable $(\mathrm{H} 6)$ as intermediate variable.

Based on it, there is direct impact of statistical indication at moral level $(\mathrm{a}=0.05)$ for the intermediate variable (H6) in the dependent variable (H7). There is a direct impact of statistical indication at moral level $(\mathrm{a}=0.05)$ for the independent variable (H1) (H2) (H3) (H4) (H5).

\section{References}

Ali, F., Zhou, Y., Hussain, K., Nair, P.K., \& Ragavan, N.A. (2016). Does higher education service quality effect student satisfaction, image and loyalty? A study of international students in Malaysian public universities. Quality Assurance in Education, 24(1), 70-94. https://doi.org/10.1108/QAE-02-2014-0008

Ancheh, K.S.B. (2006). Institutional factors attracting students to Malaysian institutions of higher education. International Review of Business Research Papers, 2(1), 46-64. 
Ancheh, K.S.B., Krishnan, A., \& Nurtjahja, O. (2007). Evaluative criteria for selection of private universities and colleges in Malaysia. Journal of International Management Studies, 2(1), 1-11.

Ariffin, A.A.M., Ahmad, A.H., Ahmad, S., \& Ibrahim, A. (2008). Determining decision-making styles and demographic differences in selecting higher education services among Malaysian. International Journal of Business and Society, 9(1), 1.

Beneke, J., \& Human, G. (2010). Student recruitment marketing in South Africa an exploratory study into the adoption of a relationship orientation. African Journal of Business Management, 4(4), 435-447.

Bin Yusof, M., binti Ahmad, S.N.B., bin Mohamed Tajudin, M., \& Ravindran, R. (2008). A study of factors influencing the selection of a higher education institution. UNITAR E-Journal, 4(2), $27-40$.

Boyer, E.L. (1987). Carnegie Foundation for the Advancement of Teaching. College: The undergraduate experience in America, 16.

Chung, K.C., Fam, K.S., \& Holdsworth, D.K. (2009). Impact of cultural values on young consumers' choice of international tertiary education. Asia-Pacific Journal of Business Administration, 1(1), 54-67. https://doi.org/10.1108/17574320910942178

Clark, C.R., \& Hossler, D. (1990). Marketing in nonprofit organizations. In D. Hossler, J. P. Bean, \& Associates, (Eds.), The Strategic Management of College Enrollments (pp. 68-85). San Francisco: Jossey-Bass.

Conklin, M.E., \& Dailey, A.R. (1981, October). Does consistency of parental educational encouragement matter for secondary school students? Sociology of Education, 54, 254-262. https://doi.org/10.2307/2112567

Espinoza, S., Bradshaw, G., \& Hausman, C. (2002). The importance of college choice factors from the perspective of high school counselors. College and University, 77(4), 19.

Foskett, N., Marine, F., \& Roberts, D. (2006). Changing fee regimes and their impact on students attitudes to higher education. Higher Education Academy, 13(2), 23-31.

Geoffrey, N.S., \& Julia, P.T. (2002). Students' preferences for university: a conjoint analysis. The International Journal of Educational Management, 16(1), 40-45. https://doi.org/10.1108/09513540210415523

Hanson, K.H., Cogan, E.S., \& Litten, L.H. (1979). Mapping the road to academe: Women, Men and the college selection process. Wellesley College, Center for Research on Women.

Hearn, J.C. (1984). The relative roles of academic, ascribed, and socioeconomic characteristics in college destinations. Sociology of Education, 57, 22-30. https://doi.org/10.2307/2112465

Hossler, D., \& Gallagher, K. (1987). Studying college choice: A three-phase model and the implication for policy makers. College and University, 2, 207-221.

Ivy, J. (2008). A new higher education marketing mix: the 7Ps for MBA marketing. International Journal of Educational Management, 22(4), 288-299. https://doi.org/10.1108/09513540810875635

Jackson, G.A. (1982). Public efficiency and private choice in higher education. Educational Evaluation and Policy Analysis, 4(2), 237-247. https://doi.org/10.3102/01623737004002237

Jafari, J., \& Aliesmaili, A. (2013). Factors influencing the selection of a university by high school students. Journal of Basic and Applied Science Research, 3(1), 696-703.

James, R., Baldwin, G., \& McInnis, C. (1999). Which University?. The Factors Influencing the Choices of Prospective Undergraduates, 99(3). Canberra: Department of Education, Training and Youth Affairs.

John, E.P.S. (1990). Price response in enrollment decisions: An analysis of the high school and beyond sophomore cohort. Research in Higher Education, 31(2), 161-176. https://doi.org/10.1007/BF00992260

John, S., \& Starkey, J.B. (1995). An alternative to net price: Assessing the influence of prices and subsidies on within-year persistence. The Journal of Higher Education, 66(2), 156-186. https://doi.org/10.1080/00221546.1995.11774771

Kee, M., \& Joseph, S. (2010). Institutional Factors Influencing Students' College Choice Decision in Malaysia: A Conceptual Framework. International Journal of Business and Social Science, 1(3).

Kellaris, J.J., \& Kellaris Jr, W.K. (1988). An exploration of the factors influencing students' college choice decision at a small private college. College and University, 63(2), 187-197. 
Keller, M.J., \& McKeown, M.P. (1984). Factors Contributing to the Postsecondary Enrollment Decisions of Maryland National Merit and National Achievement Semifinalists. ASHE 1984 Annual Meeting Paper.

Maringe, F. (2006). University and course choice: Implications for positioning, recruitment and marketing. $\begin{array}{llll}\text { International Journal of Educational } & \text { Management, } & 20(6), & \text { 466-479. }\end{array}$ https://doi.org/10.1108/09513540610683711

Milsom, A., \& Coughlin, J. (2015). Satisfaction with college major: A grounded theory study. The Journal of the National Academic Advising Association, 35(2), 5-14. https://doi.org/10.12930/NACADA-14-026

Ming, J.S.K. (2010). Institutional factors influencing students' college choice decision in Malaysia: A conceptual framework. International Journal of Business and Social Science, 1(3).

Niu, S.X., \& Tienda, M. (2008). Choosing colleges: Identifying and modeling choice sets. Social Science Research, 37(2), 416-433. https://doi.org/10.1016/j.ssresearch.2007.06.015

Seegmiller, J.F. (1975). Impressions of CEU as Expressed by Local High School Graduates.

Seymour, L. (2000). Giving the Web the new college try: Students online surf to sample life on campus. The Washington Post, 28.

Shanka, T., Quintal, V., \& Taylor, R. (2006). Factors influencing international students' choice of an education destination-A correspondence analysis. Journal of Marketing for Higher Education, 15(2), 31-46. https://doi.org/10.1300/J050v15n02_02

Somers, P., Haines, K., Keene, B., Bauer, J., Pfeiffer, M., McCluskey, J., ... Sparks, B. (2006). Towards a theory of choice for community college students. Community College Journal of Research and Practice, 30(1), 53-67. https://doi.org/10.1080/10668920500248886

St John, E.P. (1991). The impact of student financial aid: A review of recent research. Journal of Student Financial Aid, 2l(1), 2.

Wagner, K., \& Fard, P.Y. (2009). Factors influencing Malaysian students' intention to study at a higher educational institution. E-Leader Kuala Lumpur. 